\title{
Human Trafficking in Russia and Other Post-Soviet States
}

\author{
Yuliya V. Tverdova
}

Published online: 11 December 2010

(C) The Author(s) 2010. This article is published with open access at Springerlink.com

\begin{abstract}
Since the collapse of the Soviet regime, post-communist states have rapidly learned the modern face of slavery. Slavic women have been trafficked to the sex markets of Western Europe, Asia, and North America. The surge in human trafficking is the result of numerous factors, including the dramatic fall of the economic system and complete deterioration of the social safety net. This paper explores the causes and conditions of the growth of the trade in persons in the region, the profile and typical behavior of the victims, and the public perception of the trafficking problem. It identifies the inefficiencies behind the national and international responses to trafficking and the complications for policymaking associated with the stigma attached to sex workers.
\end{abstract}

Keywords Human trafficking $\cdot$ Russia $\cdot$ Sex work $\cdot$ Slavic women

\section{Introduction}

On November 3, 1989, crowds of people demolished the Berlin Wall. The Soviet Empire had collapsed. The world, or at least a big part of it, joined in the celebration and promised to help reform the old communist system. The grim reality of the post-communist transition hit hard and fast. Freedom came with a new form of modern slavery-human trafficking. Human trafficking involves the acquisition and transportation of people to a different geographical locale to profit from their labor (Aronowitz 2001; Repetskaia 2005). Annually, the total number of trafficking victims around the world approaches 900,000 (U.S. State Department 2006). Estimates of the people trapped in forced labor range from 4 to 27 million (Buckley 2009b). Criminal groups involved in human trafficking generate over US \$3.5 billion per year (Stoecker 2005). A 2006 UN report named

Y. V. Tverdova $(\bowtie)$

University of California, SSPA 4117, Mail code: 5100 Irvine, CA, USA

e-mail: tverdova@uci.edu 
127 countries of origin and 137 countries of destination of human trafficking (UNODC 2006).

Although historically silent about human trafficking, the Russian government declared trafficking in people a threat to national security in 2004. By then, a number of NGOs like Syostri (Sisters), along with some scholars and a representative from the Duma ${ }^{1}$ pushed for a change in the Russian criminal legislation to include an antitrafficking law (Shelley and Orttung 2005; Buckley 2009b). Although more narrow than the activists and what the U.S. State Department wanted, new legislation was adopted in 2003 (Buckley 2009b).

This paper provides insight into the nature of human trade in Russia and the other former Soviet Union states. Specifically, it delves into the causes of sex trafficking, develops a portrait of the victim and her typical behavior, and addresses public perceptions about the state of human trafficking and the trafficked. The study concludes by evaluating current anti-trafficking efforts in the former Soviet republics.

\section{Academic Research on Human Trafficking}

Since the mid-1990s, most explanations of human trafficking revolve around the economic concepts of supply, demand, risks, and profits (Salt and Stein 1997; Hughes 2000; Shelley 2003). High demand for sexual services and cheap labor in more developed countries is met by an ample supply of women and children, and some men from poor nations. The covert nature of human trade, the underdevelopment of the laws against trafficking, the strong reluctance of the victims to press charges and testify against their captors, and lenient sentences make it a lowrisk criminal activity with high profit margins.

The supply-side of human trafficking has been studied in greater detail than the demand-side. Much of this literature focuses on the mechanisms of trafficking, namely the recruitment, transportation, and exploitation of the victims as well as the criminal networks involved in the business (Caldwell et al. 1997; Schloenhardt 1999; Shannon 1999; Aronowitz 2001; Viuhko 2010). In contrast, the demand-side of trafficking has received significantly less attention, but, as some note, needs to be addressed in order to fight trafficking effectively (Bertone 1999; Taylor and Jamieson 1999).

Studies of human trafficking related to economic and political upheaval, represent a special segment of the economic argument. Hughes (2002) and Klopcic (2004), for example, point to the devastating effects of economic downturns and militarized disputes for the increased vulnerability of women and children. The presence of international forces increases the demand for sexual services thus fueling trafficking (Tritaki 2003; Agathangelou and Ling 2003; Farr 2005; Mendelson 2005; Allred 2006; Hughes et al. 2007; Zimelis 2009; Smith et al. 2008).

While early accounts of human trafficking sought to define and publicize the problem (IOM 1995; Caldwell et al. 1997; Chuang 1998; Graycar 1999; Kyle and Koslowski 2001), recent studies are devoted to legal issues and anti-trafficking policies (Derks 2000; Kelly and Regan 2000; Gallagher 2001; Ryf 2002; Bishop 2003; Richards

\footnotetext{
${ }^{1}$ The Duma is the lower house of the Russian legislative branch.
} 
2004; Hyland 2001; Shigekane 2007). A major difficulty in the literature is the lack of unified standards to assess the outcome of the anti-trafficking efforts (Laczko 2002; Laczko and Lee 2003; Laczko and Gozdziak 2005). The evaluation process is complicated by the scarcity of reliable data (Savona and Stefanizzi 2007). For that same reason, quantitative studies of human trafficking are exceptionally rare (Goździak and Bump 2008), whereas qualitative studies commonly draw on individual accounts of former trafficking victims (Cadet 1998; Bales and Trodd 2008).

Most of the evidence on human trafficking from the former Soviet bloc is anecdotal and comes from non-government women's groups (Shelley 2003; Orlova 2004; Stoecker 2005; Shelley and Orttung 2005; Sulaimanova 2006; Buckley 2009a, b). Academic research in the region is scarce and mostly has been produced in the past decade (Shelley 2003; Orlova 2004; Stoecker 2005; Shelley and Orttung 2005; Sulaimanova 2006; Buckley 2009a, b). A major obstacle to research on the topic, of course, is the criminal, and therefore, secretive nature of the business of human trafficking. There are substantial risks associated with this information gathering. For example, a Russian journalist was severely beaten after publicizing the research of a Russian scholar, Lyudmila Erokhina, on the collusion between traffickers and the tourist industry (Stoecker 2005).

Still, we do know a few facts about human trafficking. First, many more women than men are victims of trafficking. Sex industries act as primary employers of trafficked women, although women are also used in domestic services (Hughes 2000; Tsutsumi et al. 2008). Second, we know the major exporter and importer states and the transit routes of trafficked victims (Stoecker 2005; Shelley 2005; Shelley and Orttung 2005; Buckley 2009b). Third, we have a general profile of the trafficking victims (Bertone 1999; Shelley 2005). Fourth, we know how traffickers recruit potential victims and the conditions of their work (Erokhina 2005; Waugh 2006). Fifth, the number of prosecutions and convictions for trafficking are painfully small, primarily due to the victims' reluctance to press charges (Zakhari 2005; Sulaimanova 2006; Buckley 2009b). Finally, individual countries and the international community are not yet effective in fighting human trafficking or protecting and rehabilitating its victims (Tiuriukanova 2005; Zakhari 2005; Buckley 2009b).

Every year between 20,000 and 60,000 Russian women become victims of traffickers, and no less than 500,000 have been trafficked from the country since the collapse of the Soviet Union (Buckley 2009b). Russia has become one of the largest exporters of women for the sex industry (UNODC 2006). Russia also provides multiple transit routes for human traffickers from the poorer countries of the former Soviet Union (V Bashkirii Zaderzhan 2010; V Novosibirske Osuzhdena 2010; 40 Chelovek Soobschili 2010; Ruzanova 2008). The economic explanation for the expansion of human trafficking, however strong, does not paint the full picture of the problem in the post-Soviet states. What follows is an attempt to explicate the factors that contribute to the explosion of human trafficking, especially for sexual exploitation, in Russia and other former Soviet republics. Along with the economic and legal explanations behind trafficking, I focus on the social and psychological aspects of modern slavery in Russia. The consequences of gender inequality, patriarchic traditions, the mythology of prostitution, and the sexual revolution created a unique combination of factors contributing to the upsurge in sex trafficking and exploitation. 


\section{Romanticizing Prostitution}

Prostitution at a mass level has existed in Russia since the end of the seventeenth century (Bernstein 1995; Malakhov 2001). The status of the profession changed with each new monarch from the criminalization of prostitution to its strict state regulation to the requirement that prostitutes should wear special yellow dresses. At the second half of the nineteenth century in tsarist Russia, most prostitutes came from the peasantry. After the abolition of serfdom at the peak of industrialization, freed peasants rushed to the cities in search for work. Unable to find employment, many women turned to prostitution. Interestingly, the methods used to recruit sex workers at that time bear a strong resemblance to the modern schemes. For instance, special recruiters went to the countryside to lure unsuspecting female peasants with the prospect of high-paying jobs in urban centers and subsequently forced them into prostitution (Malakhov 2001).

In the first years after the Bolshevik Revolution, the communist state launched a vigorous campaign against prostitutes, who, by Lenin's order, were sometimes executed and sent to labor camps (Malakhov 2001). "Communism is the grave of prostitution," was declared by the State Commission to Fight Prostitution in 1919 (ibid.). This policy, however, was eased in the early 1920s with a partial return to a market-based economy and the general improvement of economic conditions (ibid.). In addition, the rejection of the institution of marriage and family by some prominent communist officials as "bourgeois" and obsolete led to a new surge in prostitution. Starting in 1929 prostitution, however, was once again brutally repressed and almost completely eliminated during Stalin's rule (ibid.).

During the balance of the Soviet era, prostitution survived in the underground and ceased to be a topic of public discussion (Namedni 1987). This changed in 1986 with the publication of an investigative report in one of the leading Moscow newspapers about the work of elite prostitutes exclusively servicing foreign clients (ibid.). The life of elite prostitutes was portrayed as carefree and prosperous in television and later in a hit movie "Interdevochka." This mythology of prostitution in the media infiltrated the culture. According to two public opinion polls conducted among high school girls at the end of 1989, prostitution made the top ten of the most prestigious and desirable professions (ibid.).

\section{Sexual Revolution in Russia}

The first years of perestroika opened a public conversation about sex-related topics in general. For instance, two TV journalists, Phil Donahue and Vladimir Posner, hosted a series of live broadcasts between studio audiences in the United States and Russia. In one of the broadcasts, a woman from Boston complained that commercials in the U.S. overexploited sexual images and inquired whether that was the case in the USSR. "There is no sex in the USSR," was the answer given by a female audience member on the Russian side. She meant to say "on television," but the end of the statement drowned in the sea of laughter on both sides of the ocean. This phrase has since become a popular joke, but, as common wisdom goes, there is a grain of truth in every joke (Znamenitoi Fraze 15 Let 2001). 
Sexuality, condemned by the communist ideology as a capitalistic vice, had not been a part of public discourse since the 1920s (Namedni 1993). Now in the late 1980 s, sexuality was embraced and celebrated by the younger generation as a symbol of changing times and perestroika. Sexual freedom became politicized as a form of protest against the old regime. Sex shops sprouted in big cities and drew so much curiosity that the owners were able to charge an entrance fee. By 1993, as newspaper sales were rapidly falling, an erotic publication, "SPID-Info," emerged as the leader in the printed media with monthly sales of 4 million copies (Namedni 1993). The production and distribution of pornography was unregulated, and pornographic videos were widely available. Women's fashions became minimalist and provocative. Short skirts, low-cut shirts, high heels, and heavy makeup dominated the fashion trend and were meant to send a concrete message to the rest of the world: I am free, I am sexy, and I am proud of it (Namedni 1988).

Rapidly growing prostitution was a by-product of the belated sexual revolution. Inspired by media and movies, young girls were no longer ashamed to offer their bodies for sale. Some college students and young female professionals saw it as an easy way to make extra money while pursuing their main career goals. Others moved to Moscow and other cities to work at night clubs and restaurants, which commonly implied stripping and prostitution (Meshkov 2008).

This expression of female sexuality and freedom occurred as men felt more freedom to violate a woman's body (Pilkington 1996; Zabelina 1996; Buckley 1997). The number of rape reports skyrocketed in the late 1980s and early 1990s (Johnson 2005). Men excused themselves by arguing with young girls and women incited sexual assaults with provocative dress, talk, and behavior (Khodyreva 2004; Johnson 2005).

\section{Economic Underpinnings of Human Trafficking}

The collapse of the Soviet regime and the economic shock that hit the former communist countries resulted in the immediate deterioration of the living standard among the general population (Ashwin 2006; Lavigne 2007). Women, however, suffered more severe economic consequences than men. Unemployment, nonexistent under communism, was much higher in the female labor force, and women had more difficulties transferring from the public to the private sector due to the widespread social stigma (Bridger et al. 1995; Kay 2006; Ashwin 2006; Shvedova 2009). Those able to keep their jobs experienced terrible wage delays, which lasted for months and, in some cases, even years (Ashwin 2006). Unimaginable hyperinflation in the 1990s made money worth less by the day, and the bankrupt government was unable to provide a safety net.

\section{Lawlessness and Corruption}

The absence of a functional legal system played a substantial role in the rise of human trafficking. Although the communist regimes fell almost overnight, the old legal systems were not rapidly replaced. The nascent Russian democracy inherited most of its criminal laws from the former Soviet legal code, where human trafficking was not prohibited or even defined. The old Soviet systems had laws against rape 
and kidnapping, but no laws for domestic abuse or other broad prohibitions that could be used to prosecute traffickers. Domestic violence, when reported, was prosecuted under the article "hooliganism." Thus, human trafficking victims could expect very little legal protection from traffickers unless they were raped or kidnapped. It took over a decade after independence to introduce a law specifically targeted at traffickers (Shelley and Orttung 2005; Buckley 2009b).

Naturally, the existence of laws prohibiting human trafficking does not guarantee effective prosecution. Often, law enforcement personnel are participants in the crimes (Sulaimanova 2006; Kara 2009; Kozlova 2009). Women forced into prostitution by traffickers have exceptionally low trust in law enforcement agencies after being raped by policemen or having had policemen as clients (Waugh 2006) and the Russian police are one of the mostly distrusted government institutions (WCIOM 2010a, b).

Corruption is rampant across the political and governmental institutions of Russia (e.g., Ledeneva 2006). Obtaining forged documents or crossing the Russian border takes no more than a bribe. Corruption makes the job of a trafficker much easier and less risky. In recent years, Russia has become one of the largest exporters in the human trade and a major transit route for human trafficking between Asia and Europe (Buckley 2009b). Women from Moldova and Ukraine, as well as Central Asian countries, are transported to Russia before being trafficked to the Balkans, Western Europe, China, Japan, South Korea, and the U.S. (Pyshschulina 2005). Russia has also been an importer of slave labor mostly from Central Asia as Uzbeks and Turkmens get smuggled into Russia and become enslaved as a result of their illegal status.

\section{Public Opinion About Human Trafficking}

In 2008, a reporter from a major Russian newspaper, Aleksandr Meshkov, gave an interview to an independent radio station in Moscow about his investigation into the topic of human trafficking (Meshkov 2008). For his field study, he traveled to a small town, Ivanovo, 170 miles from Moscow and set up a mock recruitment agency offering work for young women as escorts in the Russian capital. After placing an ad in a number of local newspapers, he received about 30 calls in 2 days and, subsequently, conducted job interviews with these women. His major claim was that all of these women had no illusions about the kind of work they would be expected to do and some had been doing similar work in Ivanovo, and viewed the opportunity to move to Moscow as a job promotion. Based on these interviews, he boldly asserted that women who set on the path of prostitution do so because of laziness and desire to attain sexual pleasure and economic prosperity (ibid.).

Meshkov reported that his investigation did not reveal any signs of forced prostitution. As evidence, he told a story of a brothel in Spain that employed Russian prostitutes. When he confronted the owner about forcing the women to work, the owner fired one of the women. Meshkov claimed the fired woman was so terrified of losing her job that she offered to work for free in exchange for staying in the brothel. He then alleged that all women working abroad as sex workers were making good money, supported their relatives at home and, upon their return back to Russia, 
bought cars and built summer houses. Eventually, he reluctantly admitted that forced prostitution might exist, but only to a very limited extent (ibid.).

Meshkov's conceptualization of sex workers as libido driven, lazy people, who choose prostitution is widespread among the public (Erokhina 2005). Moreover, Meshkov is a media elite who writes for a major daily newspaper which boasts a monthly circulation of over 30 million copies (Komsomol'skaia Pravda, ID, ZAO 2010). Although the effect of any particular publication or broadcast is hard to estimate, stories like this certainly do nothing to change the existing popular misperceptions about human trafficking and sexual exploitation.

In fact, most Russians are convinced that women trafficked for prostitution are aware of the potential nature of their employment (Kleimenov and Shamkov 2005). In other words, when they sign contracts to work as dancers, waitresses, au pairs, or house cleaners, the perception is that women know and consciously accept that these jobs actually entail sexual services (Bitkina 2004; Tiuriukanova 2005). As with domestic violence cases, when women are ready to blame themselves for saying the wrong thing thus provoking abuse, many trafficking victims feel that it is their own foolishness that got them into the situation (Kara 2009).

The existing anecdotal evidence demonstrates both Russian men and women are ready to blame the victim. Former sex slaves report that they are rejected by both the society and their own families (Buckley 2009a). These stories are echoed by the accounts of women's crisis centers' workers (Waugh 2006). A study by Buckley provides the first scientific look into the public views on the nature and origins of human trafficking in Russia (ibid.). Based on the data from a random sample of 1,600 Russian citizens, she concluded that most Russians underestimated the scale of the problem (ibid.). Only a third of the survey participants agreed that the problem with human trafficking in Russia was substantial (ibid.). Under 18\% admitted that they did not know enough to answer the question. ${ }^{2}$ Around $41 \%$ of the respondents assigned blame for trafficking on victims while about $41 \%$ believed women were duped by criminal gangs or sold into slavery by parents and friends $(32.8 \%$ and $9.1 \%$, respectively). Approximately, a third of the survey participants thought that the trafficked were mainly prostitutes hoping to earn more abroad. This view is shared by a number of deputies in the State Duma who argued against the antitrafficking law on the grounds that trafficked women are somehow unworthy of help (Buckley 2009a). Over $88 \%$ of the respondents viewed prostitution as a poor way for a woman to earn money and over $61 \%$ viewed it as morally unacceptable (Buckley 2009a); however, $41 \%$ of the respondents believed that the Russian government should arrange psychological counseling for the victims of trafficking and almost $31 \%$ thought that the government should guarantee shelter and protection for these women (ibid.). Still, 15\% believed that the women should be left alone to sort out

\footnotetext{
${ }^{2}$ For comparison, the results of a 2006 national survey in Japan (one of the major importers of sex workers from the former communist states) revealed that over $55 \%$ of the population knew nothing or did not know much about the state of human trafficking into the country. Almost $83 \%$ admitted they knew little, if anything, about the anti-trafficking policies in Japan, but 47\% believed that the women should be strictly regulated versus $45 \%$ thought they should be offered protection and support. Although $77 \%$ of the respondents believed that women work as prostitutes reluctantly, only $6 \%$ thought they could be forced to do so (Nami and Keiko 2009).
} 
their lives, and 4\% even suggested they should be punished (ibid.). A large proportion of the survey participants chose the option suggest that trafficking returnees should be sent home to their families while about $9 \%$, in contrast, argued they should be sent back to the countries they came from (ibid.).

In an earlier study, Kleimenov and Shamkov (2005) collected opinions on human trafficking among experts, ordinary citizens, and law enforcement officers. Although the results of the questionnaire revealed a high level of awareness of human trafficking even among the general public (85\% at least "heard about cases like this"), only a little over a third of the respondents thought that it was widespread (Kleimenov and Shamkov 2005). Unsurprisingly, the level of awareness among the experts and law enforcement officers was higher; however, similarly to the general population, only a third of them believed the phenomenon was widespread (ibid.).

Labor exploitation on farms, construction sites, and private homes was named as the most prevalent form of slavery (ibid.). Among the experts and law enforcement officers who responded to the survey, less than half (43\%) believed that women were sexually exploited (ibid.). Most, however, were convinced that the majority of women going abroad were local prostitutes who went there to make more money (ibid.). The same group of respondents also felt that due to media coverage about women sold into prostitution abroad, potential job seekers should be well aware of this possibility and those who go agree to take the risks (ibid.).

Contrary to the common belief, research conducted among women who consider working abroad indicates that most, in fact, do not know what kind of work may be in store for them and many have unrealistic expectations (Sulaimanova 2006). Out of 1,200 young women studied by Khodyreva and Tsvetkova, only $10 \%$ were prepared to work in prostitution or work around sexual services (Khodyreva and Tsvetkova 2000; Khodyreva 2004, 2006, cited in Buckley 2009a). Accounts of victims also revealed that some rescued women were in shock when they found out they would have to perform sex acts, while some knew or at least suspected (Waugh 2006). None of the women could imagine the conditions of that work (ibid.). Working $10-$ $12 \mathrm{~h}$, having unprotected sex with up to 10 men a day, being beaten, raped, and deprived of most basic freedoms is appalling by any standard, even if a woman made a conscious choice to become a prostitute (Gulcur and Ilkkaracan 2002). The conditions of this work are so deplorable that some activists call it a "slow genocide of women" (Waugh 2006, 64).

\section{Typical Victims}

Surveys by Kleimenov and Shamkov (2005), suggest most trafficked victims are representatives of marginalized groups, like the unemployed, homeless, prostitutes and orphans. Other accounts suggest that trafficked women are representative of the general female population within a particular age group (Shelley 2005). The truth may lie in the middle, with the majority of trafficking victims coming from lower socioeconomic strata (Stoecker 2005; Repetskaia 2005). While previous studies of trade in people in Asia, Latin America and Africa portray the typical victim as a young, poor, uneducated female, Russia and other states of the former Soviet Union, however, present one major exception to this rule (Stoecker 2005). Despite the fact 
that many of the exported Russian sex slaves came from desperate economic situations, many of them also have college degrees (Stoecker 2005).

There are at least two major explanations for why highly educated Russian women fall victim to traffickers. First, the post-communist transition negatively affected all social groups in Russia. A part of the former state-owned economy, the highly educated experienced the same harsh wage arrears, job losses, and hyperinflation as their less educated counterparts. Second, a college degree is not a safeguard from naïveté, especially during systemic political and social transition. Desperate for work, young female college graduates sought employment opportunities abroad. Although well educated, they had very limited knowledge of life outside of Russia due to the isolationist policies of the Soviet Union. Whereas during the communist times, Western countries were portrayed as evil powers, after the Soviet collapse, the West suddenly became a symbol of luxury and economic prosperity.

\section{Victims' Response to Trafficking}

The behavior of the trafficked contributes to widespread underestimation of the human trafficking problem. Survivors of trafficking are often threatened with death by traffickers if they try to leave or cooperate with law enforcement (Waugh 2006). They also often face rejection by their home communities and even their own families for their involvement in the sex industry (ibid.). Trafficking survivors often make every effort to keep their experience a secret (ibid.). Psychologically, the avoidance of judgment or condemnation from others that might accompany disclosure may help these survivors cope with their experience (ibid.).

Evidence collected by NGOs across the former Soviet states depicts a sad reality for the victims of trafficking even if they escape (Kara 2009). Upon their release from captivity, many women are found to be in the violation of immigration laws and returned to their home countries (Waugh 2006; Bernat and Zhilina 2010). Some nations like the United States, Italy, and the United Kingdom have provisions for a grace period during which victims are allowed to stay in the country under specific conditions, commonly requiring their cooperation with the law enforcement (Waugh 2006; Simeunovic-Patic 2010). Even in the rare cases when former victims agree to help prosecutors and testify in court against traffickers, they have few resources and little protection against retaliation (Waugh 2006).

Despite the trauma, many of the former trafficking victims are willing to make another attempt to go abroad for work (Kara 2009). The testimony of a 23 year old Moldovan woman, Katia, paints a horrifying picture of the situation those formerly trafficked face upon their arrival home (ibid.). After her father's death, Katia, who lived with her mother in a small town in Moldova, signed up to work in a foreign country (ibid.). A female recruiter made arrangements for her to travel abroad for work. Katia was fifteen at that time. She serviced men in four different countries for 3 years and was finally deported by Dutch authorities. When she returned, her mother had died and Katia was homeless. She was captured by a group of men and transported to Turkey for prostitution. She ran away 1 day and returned to Moldova. Unable to find a job yet again, Katia signed up for what she thought was work as a 
housekeeper in the UK. Instead, she ended up as a prostitute in a club in Moscow (Kara 2009).

What could possibly explain Katia's and other re-trafficked women's behavior? The first answer is poverty. After returning to their homes, trafficking victims face the same economic challenges and employment prospects that initially led them abroad. Unable to survive, they may turn back to traffickers. For some, psychological dependence on their abusers may also explain the return to traffickers (Waugh 2006; Kara 2009). After living under the control of their captors, they may have a difficult time adjusting to living in society (Waugh 2006; Tsutsumi et al. 2008). Russian society also tends to blame the women and, upon return, they are rejected by the local community (Erokhina 2005; Kara 2009). Unable to return to the fold of society, returnees face an enhanced risk of being re-trafficked (Waugh 2006; Kara 2009).

For most people, who have never been trafficked, held hostage, and brutally abused, the behavior of trafficking victims may seem perplexing. The victims fall into the same trap signing up with new traffickers and being re-trafficked. They do not always escape when an opportunity presents itself and instead choose to stay with their abusers. They are highly reluctant to cooperate with the law enforcement and testify against those who trafficked them into prostitution. They are not even always willing to use the services offered to them by relief groups (Waugh 2006).

Besides the economic and psychological dependency on their captors, this behavior may have a number of explanations. First, many trafficking victims from the former Soviet States have experienced domestic violence before they were trafficked (Shelley 2005; Kara 2009). According to a women's group in Moldova, seven out of ten trafficking victims are also victims of domestic abuse (Kara 2009). As a result, women become desensitized to violence, including sexual assault, and are less likely to seek outside help (ibid.). Second, because of their trafficking experience, women have low trust in the authorities often because of first-hand experiences of the collusion between traffickers and law enforcement officers (ibid.). Third, assistance from relief groups may be too temporary to help (Waugh 2006). Significantly underfunded, relief groups do not typically offer transitional housing, financial support, medical and psychological services, or legal assistance. Without a job, a place to live, and any financial help, women have nowhere to turn, but back to traffickers. Fourth, where prostitution is illegal. women refuse to involve the authorities because they themselves might face charges (Waugh 2006).

\section{Anti-Trafficking Efforts}

Perhaps, the biggest question for the international community about human trafficking is how to effectively combat it. There are individual success stories from relief groups (Tiuriukanova 2005; Waugh 2006; Ferdean 2008) but these do not easily translate into a global and systemic solution. The complexity of the trafficking problem calls for a comparably complex effort to combat it. Because enormous investigative and legal efforts are needed to rescue women from traffickers, the most efficient first step may be prevention. The reduction of poverty would diminish the economic incentives associated with human trafficking. Social programs for the 
underprivileged, including education, vocational training, subsidized childcare, and affordable housing could reduce the incentives to turn to traffickers. While costly and perhaps difficult to implement, these types of efforts could prove less costly than the current system which tolerates rampant human trafficking.

More feasible alternatives may consist of grassroots information campaigns to educate people about human trafficking. Beginning in 2009, for example, all Ukrainian schools are required to dedicate a class to teach children about antitrafficking efforts in the country (Ukrainskikh Shkol'nikov 2009). Anti-trafficking advertising campaigns should be conducted on a massive scale (Tiuriukanova and Dzialoshinskii 2008). At present, most of the information about trade in persons in Russia is delivered in the form of sensational stories in newspapers and on television, as well as occasional brief reports in the criminal news (Buckley 2009b). Whereas the latter may remain unnoticed, the former are perceived as individual cases rather than a massive phenomenon. The majority of the Russian population, including law enforcement officers, underestimates the scale of human trafficking. Public opinion in Russia and elsewhere is also negatively biased against victims of trafficking. Shockingly, focus group participants, law enforcement officers, and journalists investigating the issue at times use spiteful, demeaning language when talking about victims (Erokhina 2005).

The major obstacle in the way of effective policy is pervasive corruption. In the 2009 Transparency International report, Russia received a score of 2.2, which puts it on the 146th place among 180 nations surveyed that year (Corruption Perception Index 2009). Corruption is as rampant in other former Soviet republics such as Ukraine and Moldova which have also suffered from a rapid increase in trafficking in people (ibid.). According to the same report, Ukraine shares the 146th place with Russia as well as Zimbabwe and Sierra Leone, while Moldova is on the 89 place with a score of 3.3 (ibid.) ${ }^{3}$

Having limited resources to stop the sex trade, many NGOs and crisis centers for women deal with the survivors of human trafficking (Derks 2000; Tiuriukanova 2005). In fact, women's organizations are credited with raising public awareness about the issue and lobbying the state for anti-trafficking legislation and funds to provide support for the victims (Buckley 2009b). A wide network of crisis centers for the trafficked both in the host and home countries is absolutely necessary for reducing trafficking and re-trafficking (Ferdean 2008; Tsutsumi et al. 2008). If the rescued victims have a place to stay, legal, medical and psychological support and, a clear vision of how to change their lives they will be more likely to bring charges against their captors and less likely to be re-trafficked (Simeunovic-Patic 2010).

A growing number of nations have addressed the other side of trafficking - the demand-side (Yen 2008; Sanders 2009). In 1998, Sweden was the first country that made illegal the purchase (but not the sale) of sexual services (Ekberg 2004; Munro 2006). Behind this legislation is the underlying logic that prostitution essentially represents violence against women (Farley 2004). Other Scandinavian countries,

\footnotetext{
${ }^{3}$ The Corruption Perception Index (CPI) released by Transparency International on an annual basis ranges from 0 to 10 , with 10 being the least corrupt. It is a poll of polls based on a set of surveys mostly conducted among international business elites and country experts, but occasionally supplemented by mass public opinion surveys.
} 
such as Norway and Finland, followed the suit and subsequently adopted similar laws (Strom 2009). Because the upsurge of human trafficking into the developed countries is often associated with the increased demand for sexual services, criminalizing the purchase of sexual services or at least allowing it only in strictly monitored brothels may be an alternative way of pushing down the demand for prostitution.

To protect people, women and children in particular, from the atrocities of modern slavery, repressive (along with educational) measures may be necessary to deter traffickers as well as men, the primary customers for trafficked women, carelessly buying sex from enslaved women. There are no more important human rights than the right for life and freedom from slavery - the rights brutally violated by traffickers, whose business is perpetuated by the users of slave labor. We must protect them first.

Open Access This article is distributed under the terms of the Creative Commons Attribution Noncommercial License which permits any noncommercial use, distribution, and reproduction in any medium, provided the original author(s) and source are credited.

\section{References}

“40 Chelovek Soobshchili o Faktakh Torgovli Liud'mi v Krasnii Krest (Sankt-Peterburg).” Regnum. http:// www.regnum.ru/news/1277974.html. Accessed 26 April 2010.

Agathangelou, Anna M. and Lily H.M. Ling. 2003. "Desire Industries: Sex Trafficking, UN Peacekeeping, and the Neo-Liberal World Order." Brown Journal of World Affairs Summer-Fall, 10(1): 133-148.

Allred, Keith J. 2006. "Peacekeepers and Prostitutes: How Deployed Forces Fuel the Demand for Trafficked Women and New Hope for Stopping It." Armed Forces and Society 33(5).

Aronowitz, Alexis A. 2001. "Smuggling and Trafficking in Human Beings: The Phenomenon, The Markets that Drive it and the Organizations that Promote It," European Journal of Criminal Policy and Research, 9(2): 163-195.

Ashwin, Sarah (ed.). 2006. Adapting to Russia's New Labour Market: Gender and Employment Behaviour. New York: Routledge.

Bales, Kevin and Zoe Trodd. 2008. To Plead Our Own Cause: Personal Stories by Today's Slaves. New York: Cornell University.

Bernat, Frances and Tatyana Zhilina. 2010. "Human Trafficking: The Local Becomes Global," Women and Global Justice, 20(1): 2-9.

Bernstein. Laurie. 1995. Sonia's Daughters: Prostitutes and Their Regulation in Imperial Russia. Berkeley: University of California Press.

Bertone, Andrea Marie. 1999. "Sexual trafficking in women: International political economy and the politics of sex," Gender Issues 18(1): 4-22.

Bishop, Claire. 2003. "The Trafficking Victims Protection Act of 2000: Three Years Later," International Migration, 41(5): 219-231.

Bitkina, Svetlana. 2004. "Pautina dlya Lolit." Rossiiskaia Gazeta. http://www.rg.ru/2004/03/24/rabini. html. Accessed 24 March 2004.

Bridger, Sue, Rebecca Kay, and Kathryn Pinnick. 1995. No More Heroines? Russia, Women and the Market. New York: Routledge.

Buckley, Mary (ed.). 1997. Post-Soviet Women: from the Baltic to Central Asia. Cambridge: Cambridge University Press.

Buckley, Mary. 2009a. "Public Opinion in Russia on the Politics of Human Trafficking." Europe-Asia Studies, 61(2): 213-248.

Buckley, Mary. 2009b. "Human trafficking in the twenty-first century: implications for Russia Europe and the World," in Gender Politics in Post-Communist Eurasia. Linda Racioppi and Katherine O'Sullivan (eds.). East Lansing: Michigan State University Press. 
Cadet, Jean-Robert. 1998. Restavec: From Haitian Slave Child to Middle-Class American. Austin: University of Texas Press.

Caldwell, Gillian, Steven Galster and Nadia Steinozer. 1997. Crime and Servitude: An Expose of the Traffic in Women for Prostitution in the Newly Independent States. NY: Global Survival Network and International League for Human Rights.

Chuang, Janie 1998. "Redirecting the debate over trafficking in women: definitions, paradigms, and context," Harvard Human Rights Journal, 11:65.

Corruption Perception Index. 2009. Transparency International. http://www.transparency.org/policy_ research/surveys indices/cpi/2009/cpi 2009 table. Accessed 24 May 2010

Derks, Annuska. 2000. "Combating trafficking in South-East Asia: a review of policy and programme responses,” IOM Migration Research Series, No. 2, Geneva.

Ekberg, Gunilla. 2004. "The Swedish Law that Prohibits the Purchase of Sexual Services - Best Practices for Prevention of Prostitution and Trafficking in Human Beings." Violence Against Women, 10(10): 1187-1218.

Erokhina, Liudmila. 2005. "Trafficking in Women in the Russian Far East: A Real or Imaginary Phenomenon?" in Human Traffic and Transnational Crime: Eurasian and American Perspectives," Sally Stoecker and Louise Shelley (eds.). New York: Rowman and Littlefield Publishers, Inc.

Farley, Melissa. 2004. "'Bad for the Body, Bad for the Heart': Prostitution Harms Women Even if Legalized or Decriminalized.” Violence Against Women, 10(10): 1087-1125.

Farr, Kathryn. 2005. Sex Trafficking: The Global Market in Women and Children. Portland, OR: Worth.

Ferdean, Adriana. 2008. "Assistance and Protection for Victims of Human Trafficking." Revista de Cercetare si Interventie Sociala, 22: 98-107.

Gallagher, Anne. 2001. "Human rights and the new UN protocols on trafficking and migrant smuggling: a preliminary analysis," Human Rights Quarterly, 23: 975-1004.

Goździak, Elzbieta, and Micah Bump. 2008. "Data and Research on Human Trafficking: Bibliography of Research-Based Literature." Institute for the Study of International Migration, Submitted to the NCJRS, Doc. No. 224392, October 2008.

Graycar, Adam. 1999. "Trafficking in human beings.” Speech, International Conference on Migration, Culture and Crime, Israel, 7 July.

Gulcur, Leyla, and Pinar Ilkkaracan. 2002. "The 'Natasha' Experience: Migrant Sex Workers from the Former Soviet Union and Eastern Europe in Turkey." Women's Studies International Forum 25 (4):411-421.

Hughes, Donna. 2000. "The "Natasha" trade: The transnational shadow market of trafficking in women," Journal of International Affairs, 53(2): 625-651.

Hughes, Donna. 2002. "Trafficking for sexual exploitation: the case of the Russia Federation." IOM Migration Research Series, No. 7, Geneva.

Hughes, Donna, Katherine Chon, and Derek Ellerman. 2007. "Modern-Day Comfort Women: The U.S. Military, Transnational Crime, and the Trafficking of Women." Violence Against Women, 13 (9): 901922.

Hyland, Kelly. 2001. "Protecting human victims of trafficking: an American framework," Berkeley Women's Law Journal, 16: 29-71.

International Organization for Migration. 1995. "Trafficking and prostitution: the growing exploitation of women from Central and Eastern Europe," Geneva.

Johnson, Janet Elise. 2005. "Violence against women in Russia," in Ruling Russia: Law, Crime, and Justice in a Changing Society. William Alex Pridemore (ed.). Lanham: Rowman and Littlefield Publishers Inc.

Kara, Siddharth. 2009. Sex Trafficking: Inside the Business of Modern Slavery. New York: Columbia University Press.

Kay, Rebecca. 2006. Men in Contemporary Russia: The Fallen Heroes of Post-soviet Change? Burlington: Ashgate.

Kelly, Liz and Linda Regan. 2000. "Stopping traffic: exploring the extent of, and responses to, trafficking in women for sexual exploitation in the UK," Home Office, Police Research Series, Paper 125, London.

Khodyreva, Natalia. 2004. "Sexuality for Whom? Paid Sex and Patriarchy in Russia," in Sexuality and Gender in Postcommunist Eastern Europe and Russia. Alexandr Stulhoger and Theo Sandfort (eds.). New York: Haworth Press.

Khodyreva, Natalia. 2006. Sovremennie Debati o Prostitutsii. St. Petersburg: Aleteiia.

Khodyreva, Natalia, and Maria Tsvetkova. 2000. "Rossiianki i Yavlenie Treffika." Sotsiologicheskie Issledovaniya, 11: 141-144. 
Kleimenov, Mikhail and Stanislav Shamkov. 2005. "Criminal Transportation of Persons: Trends and Recommendations," in Human Traffic and Transnational Crime: Eurasian and American Perspectives," Sally Stoecker and Louise Shelley (eds.). New York: Rowman and Littlefield Publishers, Inc.

Klopcic, Alja. 2004. "Trafficking in Human Beings in Transition and Post-Conflict Countries," Human Security Perspectives, 1(1): 7-12.

Komsomol'skaia Pravda, ID, ZAO. 2010. RB.ru Russian business. http:/www.rb.ru/biz/companies/show/ 559917. Retrieved 11 Sept 2010.

Kozlova, Natalia. 2009. "Raba Liubvi pod Zakaz: Polkovnik GRU Komplektoval Zagranichnie Bordeli." Rossiiskaya Gazeta, March 31. http://www.rg.ru/2009/03/31/rabstvo.html.

Kyle, David and Rey Koslowski. (eds.). 2001. Global Human Smuggling: Comparative Perspectives. Collegeville: St. John's University Press.

Laczko, Frank. 2002. "Human trafficking: the need for better data," Migration Information Source, 1.

Laczko, Frank and June J.H. Lee. 2003. "Developing better indicators of human trafficking for Asia," Expert Group Meeting on Prevention of International Trafficking, Seoul, Korea, 22-23 Sept.

Laczko, Frank and Elzbieta Gozdziak. 2005. Data and Research on Human Trafficking: A Global Survey, Geneva: IOM Press.

Lavigne, Marie. 2007. The Economics of Transition: From Socialist Economy to Market Economy. London: Palgrave Macmillan.

Ledeneva, Alena. 2006. How Russia Really Works: The Informal Practices That Shaped Post-Soviet Politics and Business. Ithaca: Cornell University Press.

Malakhov, Aleksandr. 2001. “Tri Veka Rossiiskoi Prostitutsii.” Kommersant-Den'gi, 17-18, 5 May 2001.

Mendelson, Sarah E. 2005. Barracks and Brothels: Peacekeepers and Human Trafficking in the Balkans. Washington DC: CSIS Press.

Meshkov, Aleksandr. 2008. "Kto i Kak Organizuet Seksual'nie Razvlechenia dlia Vzroslikh.” Interview with Olga Bichkova. Svoimi Glazami, July 7. Moscow: Radio Echo Moskvi.

Munro, Vanessa. 2006. "Stopping Traffic? A Comparative Study of Responses to the Trafficking in Women for Prostitution.” British Journal of Criminology, 46: 318-333.

“Namedni 1987”. 1997. Namedni 1961-2003: Nasha Era, March 1. Moscow: NTV. http://video.google. com/videoplay?docid=-6710053822744889597.

“Namedni 1988". 1997. Namedni 1961-2003: Nasha Era, March 1. Moscow: NTV. http://video.google. com/videoplay?docid=1641985269931716530.

“Namedni 1993”. 1997. Namedni 1961-2003: Nasha Era, March 1. Moscow: NTV. http://video.google. com/videoplay?docid=-7082897323151509201.

Nami, Otsuki, and Hatano Keiko. 2009. "Japanese Perceptions of Trafficking in Persons: An Analysis of the 'Demand' for Sexual Services and Policies for Dealing with Trafficking Survivors." Social Science Japan Journal, 12(1): 45-70.

Orlova, Alexandra. 2004. "From Social Dislocation to Human Trafficking: The Russian Case." Problems of Post-Communism, 51(6): 14-22.

Pilkington, Hillary (ed.). 1996. Gender, Generation and Identity in Contemporary Russia. New York: Routledge.

Pyshschulina, Olga. 2005. "An Evaluation of Ukrainian Legislation to Counter and Criminalize Human Trafficking," in Human Traffic and Transnational Crime: Eurasian and American Perspectives," Sally Stoecker and Louise Shelley (eds.). New York: Rowman and Littlefield Publishers, Inc.

Repetskaia, Anna. 2005. "Classifying the Elements of Human Trafficking Crimes," in Human Traffic and Transnational Crime: Eurasian and American Perspectives," Sally Stoecker and Louise Shelley (eds.). New York: Rowman and Littlefield Publishers, Inc.

Richards, Kathy. 2004. "The Trafficking of Migrant Workers: What are the Links Between Labour Trafficking and Corruption?" International Migration, 42(5): 147-168.

Ruzanova, Nina. 2008. "Uzbeshnii Bizness.” Rossiiskaya Gazeta. http://www.rg.ru/2008/11/26/reg-sibir/ uzbeki.html. Accessed 26 Nov 2008

Ryf, Kara. 2002. "The first modern anti-slavery law: the Trafficking Victims Protection Act of 2000," Case Western Reserve Journal of International Law, 34: 45-71.

Salt, John and Jeremy Stein. 1997. "Migration as a Business: The Case of Trafficking," International Migration, 35(4): 467-494.

Sanders, Teela. 2009. "Kerbcrawler Rehabilitation Programmes: Curing the 'Deviant' Male and Reinforcing the 'Respectable' Moral Order.” Critical Social Policy, 29(1): 77-99.

Savona, Ernesto U. and Sonia Stefanizzi. 2007. Measuring Human Trafficking: Complexities and Pitfalls, Springer-Verlag, New York. 
Schloenhardt, Andreas. 1999. "Organized Crime and the Business of Migrant Trafficking: An Economic Analysis." Crime, Law and Social Change, 32: 203-233.

Shannon, Sarah. 1999. "Prostitution and the Mafia : The Involvement of Organized Crime in the Global Economy," in Illegal Immigration and Commercial Sex. The New Slave Trade. Phil Williams (ed.). London: Frank Cass Publishers.

Shelley, Louise (2003) Trafficking in women: the business model approach. Brown Journal of World Affairs 10:119-131.

Shelley, Louise. 2005. "Russian and Chinese Trafficking: A Comparative Perspective," in Human Traffic and Transnational Crime: Eurasian and American Perspectives. Sally Stoecker and Louise Shelley (eds.). New York: Rowman and Littlefield Publishers, Inc.

Shelley, Louise, and Robert Orttung. 2005. "Russia's Efforts to Combat Human Trafficking: Efficient Crime Groups versus Irresolute Societies and Uncoordinated States," in Ruling Russia: Law, Crime, and Justice in a Changing Society. William Alex Pridemore (ed.). Lanham: Rowman and Littlefield Publishers, Inc.

Shigekane, Rachel. 2007. "Rehabilitation and Community Integration of Trafficking Survivors in the United States." Human Rights Quarterly 29:112.

Shvedova, Nadezhda. 2009. "Gender Politics in Russia," in Gender Politics in Post-Communist Eurasia. Linda Racioppi and Katherine O’Sullivan (eds.). East Lansing: Michigan State University Press.

Simeunovic-Patic, Biljana. 2010. "Protection and Assistance to Victims of Human Trafficking in Serbia: Recent developments." European Journal of Criminology, 7(1): 45-60.

Smith, Charles Anthony and Heather M. Smith. 2008. "Human trafficking: the unintended effects of UN intervention." Paper presented at the annual meeting of the Western Political Science Association, Manchester Hyatt, San Diego, California, 20 Mar 2008.

Stoecker, Susan. 2005. "Human Trafficking: A New Challenge for Russia and the United States," in Human Traffic and Transnational Crime: Eurasian and American Perspectives. Susan Stoecker and Louise Shelley (eds.). Lahman: Rowman and Littlefield.

Strom, Agnete. 2009. "A Glimpse into 30 Years of Struggle against Prostitution by the Women's Liberation Movement in Norway." Reproductive Health Matters, 17(34): 29-37.

Sulaimanova, Saltanat. 2006. "Trafficking in Women from the Former Soviet Union for the Purposes of Sexual Exploitation," in Trafficking and the Gloval Sex Industry. Karen Beeks and Delila Amir (eds.). Lanham: Lexington Books.

Taylor, Ian, and Ruth Jamieson. 1999. "Sex trafficking and the mainstream of market culture." Crime Law and Social Change, 32(3): 257-278.

Tiuriukanova, Elena. 2005. "Female Labor Migration Trends and Human Trafficking: Policy Recommendations," in Human Traffic and Transnational Crime: Eurasian and American Perspectives," Sally Stoecker and Louise Shelley (eds.). New York: Rowman and Littlefield Publishers, Inc.

Tiuriukanova, Elena, and Iosif Dzialoshinskii. 2008. Torgovlia Liud'mi: SMI kak Resurs Obshchestvennogo Protivodeistviia Sovremennomu Rabstvu. International Organization for Migration (IOM). Moscow: ZAO "CitiPressService".

Tritaki, Panagiota. 2003. Peacekeepers and sex trafficking: supply and demand in the aftermath of the Kosovo conflict. Unpublished thesis in the Faculty of the Fletcher School of Law and Diplomacy.

Tsutsumi, Atsuro, Takashi Izutsu, Amod Poudyal, Seika Kato, and Eiji Marui. 2008. "Mental Health of Female Survivors of Human Trafficking in Nepal.” Social Science and Medicine, 66(8): 1841-1847.

“Ukrainskikh Shkol'nikov Budut Uchit', kak ne Bit' Pokhishchennimi.” 2009. Obozrevatel, June 20. http://obozrevatel.com/news/2009/6/19/308649.htm.

UNODC (United Nations Office on Drugs and Crime). 2006. "Trafficking in Persons: Global Patterns."

U.S. State Department. 2006. "Trafficking in persons annual report.” http://www.state.gov/g/tip/rls/tiprtp/ 2006/65990.htm. Accessed 4 May 2010.

"V Bashkirii Zaderzhan Torgovets Liud'mi iz Armenii". 2010. Regnum. http:/www.regnum.ru/news/ 1286179.html. Accessed 21 May 2010.

Viuhko, Minna. 2010. "Human Trafficking for Sexual Exploitation and Organized Procuring in Finland." European Journal of Criminology, 7(1): 61-75.

"V Novosibirske Osuzhdena Grazhdanka Uzbekistana za Torgovliu Liud'mi.” 2010. Regnum. http://www. regnum.ru/news/1279878.html. Accessed 1 May 2010.

Waugh, Louise. 2006. Selling Olga: Stories of Human Trafficking and Resistance. London: Weidenfeld and Nicolson.

WCIOM (Wserossiiskii Centr Izuchenia Obshchestvennogo Mnenia). 2010a. "Rossiiskaia Milicia: Geroi ili Prestupniki?" Press Release 1540. http://old.wciom.ru/arkhiv/tematicheskii-arkhiv/item/single/ 13684.html. Accessed 19 July 2010. 
WCIOM (Wserossiiskii Centr Izuchenia Obshchestvennogo Mnenia). 2010b. "Rossiiskaia Milicia: Effektivnost' Raboti I Doverie Grazhdan.” Press Release 1537. http://old.wciom.ru/arkhiv/tematicheskii-arkhiv/ item/single/13676.html. Accessed 14 July 2010.

Yen, Iris. 2008. "Of Vice and Men: A New Approach to Eradicating Sex Trafficking by Reducing Male Demand through Educational Programs and Abolitionist Legislation." Journal of Criminal Law and Criminology, 98(2): 653-686.

Zabelina, Tat'iana. 1996. "Sexual Violence towards Women," in Gender Generation and Identity in Contemporary Russia. Hilary Pilkington (ed.) Gender Generation and Identity in Contemporary Russia. New York: Routledge.

Zakhari, Beatrix Siman. 2005. "Legal Cases Prescuted under the Victims of Trafficking and Violence Protection Act of 2000," in Human Traffic and Transnational Crime: Eurasian and American Perspectives," Sally Stoecker and Louise Shelley (eds.). New York: Rowman and Littlefield Publishers, Inc.

Zimelis, Andris. 2009. "Human Rights, the Sex Industry and Foreign Troops," Cooperation and Conflict, 44(1): 51-71.

“Znamenitoi Fraze "U Nas v SSSR Seksa Net”-15 Let.” 2001. NewsRu.com. http://www.newsru.ru/ russia/17jul2001/sex.html. Accessed 17 July 2001. 